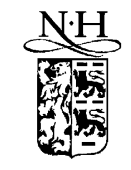

ELSEVIER

\title{
Asset liquidity, capital structure, and secured debt ${ }^{2}$ s
}

\author{
Erwan Morellec* \\ William E. Simon Graduate School of Business Administration, University of Rochester, \\ Rochester, NY 14627, USA
}

Received 15 October 1999; accepted 12 August 2000

\begin{abstract}
This paper investigates the impact of asset liquidity on the valuation of corporate securities and the firm's financing decisions. I show that asset liquidity increases debt capacity only when bond covenants restrict the disposition of assets. By contrast, I demonstrate that, with unsecured debt, greater liquidity increases credit spreads on corporate debt and reduces optimal leverage. The model also determines the extent to which pledging assets increases firm value and relates the optimal size of the pledge to firm and industry characteristics. Finally, I show that asset liquidity and security provisions may help explain leverage ratios and credit spreads observed in practice. (C) 2001 Elsevier Science S.A. All rights reserved.
\end{abstract}

JEL classification: G12; G32; G33

Keywords: Asset liquidity; Capital structure; Credit spreads; Secured debt

\footnotetext{
${ }^{2}$ I thank my dissertation adviser Bernard Dumas for invaluable guidance and Antonio Mello for detailed comments and helpful suggestions. Comments by Mike Barclay, Pascal François, Rene Stulz, and Fernando Zapatero are also gratefully acknowledged. This paper has also benefited from discussions with Cliff Smith and from comments by the referee (John Parsons) that led to substantive revisions of an earlier version of this paper.
}

*Tel.: + 1-716-273-1645.

E-mail addresses: morellec@simon.rochester.edu (E. Morellec). 


\section{Introduction}

This paper investigates the impact of asset liquidity on the values of corporate securities and the firm's financing decisions. Throughout the paper, asset liquidity is defined as the ease with which the firm's assets can be sold on a secondary market. Because higher liquidity may increase firm value in liquidation, the traditional view is that liquidity increases debt capacity (see, e.g., Shleifer and Vishny, 1992). ${ }^{1}$ However, as argued by Weiss and Wruck (1998), "unless a credible promise can be made not to engage in asset stripping, [...] asset liquidity [could] reduce, not increase, a firm's ability to issue debt securities". I contend in this paper that liquidity increases debt capacity only when bond covenants impose restrictions on the disposition of assets. In particular, I show that when the firm's assets are pledged as collateral to the debt contract, greater liquidity reduces credit spreads on corporate debt and increases optimal leverage. By contrast, I demonstrate that when the bond indenture does not include security provisions, the opposite is true. The model determines the extent to which pledging assets distorts the firm's operating policy and reduces the cost of debt financing. As a result, I am able to derive the optimal size of the pledge and to relate it to firm and industry characteristics such as asset productivity and demand uncertainty. Finally, I show that asset liquidity can help explain the leverage ratios and credit spreads observed in practice.

The imperfect competition model I develop in this article builds on earlier work on capacity choice. ${ }^{2}$ I consider an economy with a firm having exclusive access to a project that yields a stochastic continuous stream of cash flows. The firm is levered because debt allows it to shield part of its operating profits from taxation. However, leverage is limited because debt financing increases the likelihood of costly financial distress. To measure the effects of asset liquidity on the values of corporate securities, I assume that the stream of cash flows generated by assets in place is directly related to current firm size. Uncertainty is represented by the demand shift parameter for the good produced by the firm and, consequently, both the rate of cash flow accrual and the rate of asset sales are driven by its variations.

The paper derives simple valuation formulas for debt and equity when the firm's assets are divisible and liquid. Because of asset liquidity, valuable options to reduce capacity arise when economic conditions worsen. In the model, the proceeds from capacity reductions are used either to pay debt service when the firm is in distress or to pay dividends when the firm is solvent. However, management, acting in the best interest of shareholders, sells assets

\footnotetext{
${ }^{1}$ Myers and Rajan (1998) show in a related paper that greater liquidity reduces the ability of the borrower to commit to a specific course of action and, hence, its debt capacity.

${ }^{2}$ See, for example, Pindyck (1988) and Abel and Eberly (1996).
} 
only when asset sales maximize the value of equity. As a result, equity value comprises the expected present value of the cash flow to be received plus a continuum of options to reduce capacity and the option to exit the industry.

The model endogenously determines both the default threshold and the sales curve that maximize equity value. Because of the limited liability principle, shareholders have the option to default on their obligations. The optimal exercise policy for this option is to default when the firm has negative economic net worth. As a result, shareholders inject capital to finance continued operation of the firm whenever it is solvent on a stock basis but insolvent on a flow basis.

Asset liquidity expands the strategy space open to the borrower by allowing it to sell assets to meet coupon payments. Asset sales are optimal for shareholders whenever their marginal valuation of capital is lower than the selling price of assets. At the same time, asset sales are in the best interest of the firm because their proceeds exceed the marginal revenue product generated by capital. Thus, when the firm is solvent, asset sales increase firm value by allocating assets to better uses. When the firm is in distress, asset sales represent for the firm the cheapest source of funds. Moreover, asset sales allow the firm to finance continued operation of its remaining assets without requiring capital injections by shareholders, thereby increasing equity value. In the meantime, however, asset sales reduce the value of corporate debt by reducing firm size upon closure as well as the average lifetime of assets in place. In a rational expectations model, bondholders anticipate the decrease in the value of their claims and the corporate spread adjusts to yield a normal compensation.

The net effect of asset liquidity on firm value results from a trade-off between the increase in equity value and the reduction in debt value. When the value of the operating flexibility provided by asset liquidity is lower than the decrease in debt value, it is optimal for the firm to pledge assets by issuing secured debt. ${ }^{3}$ When the reverse is true, it is optimal for the firm to issue unsecured debt. Therefore, contrary to models in which the level of asset sales is exogenous (see e.g. Leland, 1994), our model predicts that bond covenants pledging assets as collateral can reduce firm value by inducing overinvestment in unproductive assets. The model also shows that the value maximizing policy consists in pledging part of the firm's assets and that the optimal size of the pledge depends on firm and industry characteristics such as asset productivity and demand uncertainty.

The closed-form results I obtain for the values of equity and debt also allow for an investigation of the effects of asset liquidity on optimal leverage. Because firm size upon closure depends on the willingness of the firm to sell assets,

\footnotetext{
${ }^{3}$ Although the analysis focuses on secured debt, other types of bond covenants relying, for example, on balance sheet ratios such as book debt/book assets would yield the same investment policy for the firm and, hence, would have the same implications for asset values and the firm policy choices.
} 
higher liquidity reduces the firm's ability to issue debt. Moreover, because asset sales raise the value of equity whereas they reduce debt value, the optimal leverage ratio is reduced. The model yields an explanation for the failure of the contingent claims analysis to replicate the low debt levels and high credit spreads observed in practice. Incorporating possible asset sales and security provisions in the model results in an increase of $10-30 \%$ of default spreads and, at the same time, a decrease of $30-60 \%$ of optimal leverage.

The remainder of the paper is organized as follows. Section 2 derives the value of the unlevered firm and discusses the moral hazard problems associated with debt financing. Section 3 presents a model of the levered firm where firm size is fixed. It also relates debt and equity values to firm and industry characteristics. Section 4 allows the firm to adjust its production capacity to economic conditions and investigates the effects of asset liquidity on leverage decisions and firm value. Section 5 introduces secured debt and analyses its efficiency implications. Section 6 concludes the paper.

\section{The model}

\subsection{Assumptions}

Throughout the paper, capital markets are perfect with no transaction costs and equal access to information for all investors. The default-free term structure is flat with an instantaneous riskless rate $r$ at which investors may lend and borrow freely.

I consider an infinitely lived firm producing output with its capital stock $k$. I assume for simplicity that the good produced by the firm is not storable so that output equals demand. The firm is initially financed by standard equity. Management acts in the best interests of shareholders. Corporate taxes are paid at a rate $\tau$ on operating profit, and full offsets of corporate losses are allowed.

The firm's instantaneous operating profit is given by

$$
\pi\left(x_{t}, k\right)=a x_{t}^{\gamma} k^{1-\gamma}-c,
$$

where $\gamma \in] 0,1\left[, a>0, c>0\right.$ and $\left(x_{t}\right)_{t \geqslant 0}$ is a demand shift parameter. ${ }^{4}$ In this equation, $a x_{t}^{\gamma} k^{1-\gamma}$ accounts for the flow of revenues minus variable costs and $c$ is a constant flow cost per period. For the remainder of the paper, $\left(x_{t}\right)_{t \geqslant 0}$ is ruled by the process

$$
x_{T}=x_{t} \exp \left\{\left(\mu-\sigma^{2} / 2\right)(T-t)+\sigma\left(Z_{T}-Z_{t}\right)\right\} \geqslant 0, \quad x_{t}>0,
$$

where $\mu$ and $\sigma$ are constant parameters and $\left(Z_{t}\right)_{t \geqslant 0}$ is a Brownian motion defined on a filtered probability space $\left(\Omega, \mathscr{F}, \mathbb{P},\left(\mathscr{F}_{t}\right)_{t \geqslant 0}\right)$.

\footnotetext{
${ }^{4}$ When $c=0$, Eq. (1) approximates the profit function of a firm using a Cobb-Douglas production technology and facing an isoelastic demand curve (see Section A.5 of Appendix A).
} 
Although its assets may be operated forever, the firm can also choose to abandon them or to reduce its production capacity. I assume hereafter that these decisions are irreversible. As a result, they may be viewed as the decision to liquidate the firm or, alternatively, to liquidate marginal units of capital. I denote the abandonment value of the firm by $A(x, k)$ and the constant selling price of assets by $l .^{5} A(x, k)$ represents the traditional measure of liquidity (used for example by Shleifer and Vishny (1992)). It depends on the current state of the industry, $x$, and current firm size, $k . l$ represents a second measure of liquidity which is relevant over the entire life of the firm. Obviously, the relation between $A(x, k)$ and $l$, i.e. between the price the firm gets for its capital upon abandonment and the price it gets now, is critical to the decision whether to sell assets now or to hold on to them.

\subsection{Value of the unlevered firm}

Before analyzing the impact of debt financing on firm value, it will be useful to identify the sources of value within the firm. The value of the unlevered firm is given by a combination of the value of assets in place and the values of the real options available to management. In particular, firm value is equal to the sum of the value of a perpetual right to the current flow of income and the values of the options to reduce capacity and abandon operations. These options can be described as follows:

1. The option to abandon the firm's assets consists of one irreversible switch that occurs the first time the state variable reaches the abandonment threshold. This decision trades off the expected present value of the cash flows associated with operation of the firm's assets with the abandonment value of the firm.

2. The contraction options consist of a sequence of irreversible switches. These switches take place at contraction thresholds that depend on the contemporaneous production capacity of the firm. The optimal contraction policy trades off the marginal decrease in the firm's expected profit with the selling price of assets.

I denote by $T_{y}$ the first passage time of $\left(x_{t}\right)_{t \geqslant 0}$ at $y$ and by $\mathbb{E}^{x_{0}}$ the expectation operator associated with the probability measure $\mathbb{P}$ conditional on $x$ starting at the level $x_{0}$. If agents are risk neutral, ${ }^{6}$ the value of the abandonment option for

\footnotetext{
${ }^{5}$ The model can be extended to the case in which the selling price of assets depends on the state of the industry $x$. However, such an extension does not yield more insights on the economics of the problem.

${ }^{6}$ When agents are risk averse, the probability measure can be changed using Cameron-MartinGirsanov theorem to develop the analysis in a risk-neutral economy (see Harrison and Pliska, 1981). This alternative approach, which relies on the dynamic completeness of financial markets, is used by He and Pindyck (1992) in a model in which firms are characterized by a technology similar to mine.
} 
a given abandonment threshold $x_{a}\left(k_{a}\right)$ can be written as ${ }^{7}$

$$
A\left(x_{a}\left(k_{a}\right), k_{a}\right) \mathbb{E}^{x_{0}}\left[\mathrm{e}^{-r T_{x_{a}\left(k_{a}\right)}}\right]-(1-\tau) \mathbb{E}^{x_{0}}\left[\int_{T_{x_{a}\left(k_{a}\right)}}^{+\infty} \mathrm{e}^{-r u} \pi\left(x_{u}, k_{a}\right) \mathrm{d} u\right],
$$

in which $T_{y}=\inf \left\{t \geqslant 0: x_{t}=y\right\}$ and $k_{a}$ is the production capacity upon abandonment. The first term of this expression represents the expected abandonment value of the firm discounted between the expected exit time and the current date. The second term accounts for the expected present value of the cash flows that the assets of the firm would have generated if the firm had not abandoned them.

The value of the contraction options can be written in the same fashion. For any given set of contraction thresholds $x_{l}(\kappa)$, the value of these options is defined by

$$
\int_{k}^{k_{a}}\left(l \mathbb{E}^{x_{0}}\left[\mathrm{e}^{-r T_{x_{l}(k)}}\right]-(1-\tau) \mathbb{E}^{x_{0}}\left[\int_{T_{x_{l}(k)}}^{+\infty} \mathrm{e}^{-r u} \pi_{\kappa}\left(x_{u}, \kappa\right) \mathrm{d} u\right]\right) \mathrm{d} \kappa,
$$

in which $\pi_{\kappa}($.$) is the instantaneous marginal revenue product of capital.$ According to this specification, the firm can reduce its capacity from $k$ to $k_{a}$. Each capacity reduction entitles the firm to the selling price of assets $l$. In the same time, firm size and the expected cash flows from continuing operation are reduced marginally.

Combining the values of these real options with the value of a perpetual entitlement to the current flow of income gives the value of the firm as

$$
\begin{aligned}
v_{a}(x, k) & =(1-\tau) \mathbb{E}^{x_{0}}\left[\int_{0}^{+\infty} \mathrm{e}^{-r u} \pi\left(x_{u}, k\right) \mathrm{d} u\right] \\
& +A\left(x_{a}\left(k_{a}\right), k_{a}\right) \mathbb{E}^{x_{0}}\left[\mathrm{e}^{-r T_{x_{a}\left(k_{a}\right)}}\right]-(1-\tau) \mathbb{E}^{x_{0}}\left[\int_{\left.T_{x_{a}\left(k_{a}\right)}^{+\infty} \mathrm{e}^{-r u} \pi\left(x_{u}, k_{a}\right) \mathrm{d} u\right]}^{k_{a}}\left(l \mathbb{E}^{x_{0}}\left[\mathrm{e}^{-r T_{x_{l}(k)}}\right]-(1-\tau) \mathbb{E}^{x_{0}}\left[\int_{T_{x_{l}(k)}}^{+\infty} \mathrm{e}^{-r u} \pi_{\kappa}\left(x_{u}, \kappa\right) \mathrm{d} u\right]\right) \mathrm{d} \kappa .\right.
\end{aligned}
$$

\footnotetext{
${ }^{7}$ Future revenues are expected to grow at the rate $\mu \gamma+\gamma(\gamma-1) \sigma^{2} / 2$. Therefore, the integrals defined below to converge to a finite solution only if $r>\mu \gamma+\gamma(\gamma-1) \sigma^{2} / 2$. Also, note that I implicitly assume that the manager makes policy choices that generate positive values for the real options available to the firm.
} 
The first best contraction policy consists in selecting the contraction thresholds that maximize firm value. Therefore, the optimal contraction thresholds satisfy the high-contact conditions (see Dumas, 1991)

$$
\left.\frac{\partial^{2} v_{a}(x, \kappa)}{\partial \kappa \partial x}\right|_{x=x_{l}(\kappa)}=0 \text { for } \kappa \in\left[k_{a}, k\right] .
$$

Solving these equations yields the following proposition.

Proposition 1. Assume that the instantaneous profit function of the firm is described by Eqs. (1) and (2). When the firm is unlevered, its value satisfies for $k>k_{a}$

$$
v_{a}(x, k)=\Pi(x, k)+p\left(k, k_{a}\right)+\left[A\left(x_{a}\left(k_{a}\right), k_{a}\right)-\Pi\left(x_{a}\left(k_{a}\right), k_{a}\right)\right]\left(x / x_{a}\left(k_{a}\right)\right)^{\vartheta},
$$

in which

$$
\Pi\left(x_{t}, k\right)=(1-\tau) \mathbb{E}^{x_{t}}\left[\int_{t}^{\infty} \mathrm{e}^{-r(u-t)} \pi\left(x_{u}, k\right) \mathrm{d} u\right]
$$

and $b=\left(\mu-\sigma^{2} / 2\right) / \sigma, \lambda=\sqrt{2 r+b^{2}}$ and $\vartheta=-(b+\lambda) / \sigma$. In Eq. (8), $p\left(k, k_{a}\right)$ accounts for the value of the options to reduce firm size from $k$ to $k_{a}$. It is equal to

$$
p\left(k, k_{a}\right)=\frac{\gamma l}{(\gamma-\vartheta)(1-\vartheta)}\left(k\left(x / x_{l}(k)\right)^{\vartheta}-k_{a}\left(x / x_{l}\left(k_{a}\right)\right)^{\vartheta}\right) .
$$

The abandonment and contraction thresholds satisfy Eq. (6). Firm size upon abandonment is defined by $x_{a}\left(k_{a}\right)=x_{l}\left(k_{a}\right)$.

Proof. See Appendix A.

To determine the optimal abandonment policy, the abandonment value of the firm must be specified further. For simplicity, I assume that the abandonment value of unlevered assets is given by a constant $L$ (possibly equal to $k_{a} l$ ). This assumption implies that the optimal abandonment threshold satisfies

$$
\left.\frac{\partial v_{a}\left(x, k_{a}\right)}{\partial x}\right|_{x=x_{a}\left(k_{a}\right)}=0 \text {. }
$$

The following results.

Proposition 2. Assume that the abandonment value of the unlevered firm is given by a constant L. Then, the abandonment threshold is given by

$$
x_{a}\left(k_{a}\right)=\left[\frac{\vartheta}{\vartheta-\gamma} \frac{(1-\tau) c+r L}{(1-\tau) r a\left(k_{a}\right)^{1-\gamma}}\left(r-\gamma \mu-\gamma(\gamma-1) \frac{\sigma^{2}}{2}\right)\right]^{1 / \gamma} .
$$


Moreover, the production capacity of the firm upon abandonment satisfies

$$
k_{a} l=(1-\gamma)\left[(1-\tau) \frac{c}{r}+L\right]
$$

and the contraction policy is described by

$$
x_{l}(\kappa)=\left(\frac{\vartheta}{\vartheta-\gamma} \frac{l\left(r-\mu \gamma-\gamma(\gamma-1) \sigma^{2} / 2\right)}{(1-\gamma)(1-\tau) a}\right)^{1 / \gamma} \kappa, \quad \kappa \in\left[k_{a}, k\right] .
$$

The equation that determines firm size upon closure can be interpreted as follows. The left-hand side of Eq. (12) is the shadow value of assets in place. The right-hand side is the opportunity cost of remaining active adjusted for asset productivity, $1-\gamma$ (the higher the productivity of assets in place, the larger firm size upon closure). Note that while firm size upon closure is increasing in $A(x, k)=L$, it is decreasing in $l$. Sections 3 and 4 show that these two measures of liquidity have a similar impact on the willingness of the levered firm to hold on to its assets and, hence, on the value of bondholders' claim upon default. As a result, increases in $A(x, k)$ increase the firm's debt capacity whereas increases in $l$ decrease the firm's ability to issue debt.

Table 1 reports simulation results associated with Propositions 1 and 2. Parameter values for the base case environment are set as follows: the riskless

Table 1

Table 1 reports comparative statics associated with Propositions 1 and 2. The abandonment value of the firm's assets is given by a constant $L$. The first column gives the value of the unlevered firm without the contraction options. The second column gives the value of the unlevered firm with the contraction options. The third column reports the relative increase in value resulting from the contraction options. The fourth column gives firm size upon exit.

The base case parameters are set as follows: The riskless interest rate $r=6 \%$, the initial size of the firm $k=100$, the productivity of assets in place $\gamma=0.53$, the corporate tax rate $\tau=15 \%$, the liquidation value of unlevered assets $L=k_{a} l$, and the selling price of assets in place $l=1$. The profit function is further characterized by $\mu=0.01, \sigma=0.2, a=1, c=1$, and $x_{0}=1$.

\begin{tabular}{lcccc}
\hline $\begin{array}{l}\text { Input } \\
\text { parameter } \\
\text { values }\end{array}$ & $\begin{array}{c}\text { Value with no } \\
\text { capacity } \\
\text { adjustment }\end{array}$ & $\begin{array}{c}\text { Value with } \\
\text { capacity } \\
\text { adjustments }\end{array}$ & $\begin{array}{c}\text { Contraction } \\
\text { options } \\
(\%)\end{array}$ & $\begin{array}{r}\text { Exit } \\
\text { size } \\
k_{a}\end{array}$ \\
\hline Base & 109.9 & 130.8 & 19.0 & 13 \\
$\gamma=0.50$ & 127.5 & 139.7 & 9.6 & 14 \\
$\gamma=0.56$ & 94.6 & 128.7 & 36.0 & 11 \\
$\sigma=0.15$ & 114.6 & 134.9 & 17.7 & 13 \\
$\sigma=0.25$ & 104.5 & 128.5 & 23.0 & 13 \\
$L=0.5 k_{a} l$ & 109.9 & 130.5 & & \\
$L=0.75 k_{a} l$ & 109.9 & 130.6 & 18.7 & 9 \\
\hline
\end{tabular}


interest rate $r=6 \%$, the initial size of the firm $k=100$, the productivity of assets in place (see Appendix A) $\gamma=0.53$, the corporate tax rate $\tau=15 \%$, and the liquidation value of unlevered assets $L=k_{a} l$. The profit function is further characterized by $\mu=0.01, \sigma=0.2, a=1, c=1$, and $x_{0}=1$.

Table 1 reveals that the real options available to the firm have important value implications. In the base case environment, for example, the contraction options increase firm value by $19 \%$. Table 1 also shows that demand uncertainty $(\sigma)$ and the productivity of the firm's assets $(1-\gamma)$ have a significant impact on the value of these options. As the productivity of assets in place increases (as $\gamma$ decreases from 0.53 to 0.5 ), it is more valuable for the firm to hold on to its assets. Thus, firm size upon abandonment increases (from 13 to 14 ) while the value of the contraction options decreases (from $19 \%$ to $36 \%$ of firm value). Surprisingly, the abandonment value of the firm's assets does not have a large impact on the value of the contraction options. This result arises because of the low probability of exit in the base case environment.

Propositions 1 and 2 determine firm value under the abandonment and contraction policies defined by Eqs. (6) and (10). These policies are optimal in the sense that they maximize firm value ex ante. I show below that debt distorts management's incentives to follow these policies, thereby creating agency costs of debt.

\subsection{Introducing debt}

Because of the tax shield, the firm has an incentive to issue debt. The design of the debt contract is essential because it affects the type of moral hazard problems associated with debt financing. I consider in this article infinite maturity debt contracts, which are characterized by:

1. A perpetual flow of coupon payments $s$ and a commitment that if the firm defaults on its obligation to service the debt contract, it is immediately liquidated. The remaining cash flows from operations accrue to shareholders (i.e. shareholders have residual income rights).

2. A principal $P$ that shareholders have to pay upon default prior to receiving any cash flow. (That is, absolute priority is enforced upon default.)

3. Bond covenants that restrict the disposition of the firm's assets prior to default. I consecutively consider covenants preventing the firm from selling assets, allowing the firm to sell its assets, or pledging part of the firm's assets as collateral to the debt contract.

In order to understand the impact of debt financing on the firm policy choices, it is important to make a clear distinction between the value of equity ex ante (at the time of the debt issuance) and ex post (once debt has been issued). The value of equity ex post is given by the present value of the cash flows accruing to shareholders after the debt has been sold. The value of equity 
ex ante is the sum of the value of equity ex post and the market value of debt at the time it is issued (i.e. firm value at that time). The contraction and default thresholds typically are selected ex post so as to maximize equity value whereas leverage and bond covenants are selected ex ante so as to maximize firm value. As a result, conflict of interest may occur between shareholders and bondholders because management does not follow ex post the contraction and abandonment policies defined by Eqs. (6) and (10).

\section{Fixed capacity and capital structure}

Consider first the case in which bond covenants prevent the firm from adjusting its production capacity to economic conditions. The relevant measure of liquidity is thus $A(x, k)$. In this setting, agency costs of debt result exclusively from an inefficient abandonment decision. Moreover, debt affects firm value because it changes both the amount of taxes paid by the firm and expected bankruptcy costs. This is the standard case studied, for example, by Mello and Parsons (1992).

\subsection{Valuation of debt and equity}

I denote the values of debt and equity claims when the firm has issued debt with contractual coupon payment $s$ by $d(x, k, s)$ and $e(x, k, s)$. Shareholders have limited liability and, thus, the option to default on their obligations. ${ }^{8}$ The optimal policy for shareholders is to default when the continuation value of equity is lower than its liquidation value (to be received if and when default occurs).

I denote the proportional bankruptcy cost incurred upon default by $\alpha$ and the default threshold selected by shareholders by $x_{d}(k)$. If absolute priority is enforced, the cash flow to shareholders upon default is

$$
\max \left[(1-\alpha) A\left(x_{d}(k), k\right)-P, 0\right],
$$

whereas the cash flow to bondholders is

$$
\min \left[(1-\alpha) A\left(x_{d}(k), k\right), P\right] .
$$

Using the above notations, the values of equity and debt can be written as the sum of the present value of the cash flows that claimholders receive upon continuation (until $T_{x_{d}(k)}$ ) and the present value cash flow that they receive

\footnotetext{
${ }^{8}$ In the model, bankruptcy is triggered instantaneously by the decision of shareholders to cease injecting funds in the firm. This condition relies on a stock-based definition of financial distress. A similar condition can be found in Mello and Parsons (1992) and Leland (1994).
} 
upon default:

$$
\begin{aligned}
e(x, k, s)= & (1-\tau) \mathbb{E}^{x_{0}}\left[\int_{0}^{T_{x_{d}(k)}} \mathrm{e}^{-r u}\left(\pi\left(x_{u}, k\right)-s\right) \mathrm{d} u\right] \\
& +\max \left[(1-\alpha) A\left(x_{d}(k), k\right)-P, 0\right] \mathbb{E}^{x_{0}}\left[\mathrm{e}^{-r T_{x_{d}(k)}}\right],
\end{aligned}
$$

and

$$
\begin{aligned}
d(x, k, s)= & \mathbb{E}^{x_{0}}\left[\int_{0}^{T_{x_{d}(k)}} \mathrm{e}^{-r u} s \mathrm{~d} u\right] \\
& +\min \left[(1-\alpha) A\left(x_{d}(k), k\right), P\right] \mathbb{E}^{x_{0}}\left[\mathrm{e}^{-r T_{x_{d}(k)}}\right] .
\end{aligned}
$$

Solving these equations yields the following proposition.

Proposition 3. When the instantaneous profit function of the firm is described by Eqs. (1) and (2) and bond covenants prevent the firm from selling assets, firm value for a fixed flow of coupon payments satisfies

$$
v(x, k, s)=e(x, k, s)+d(x, k, s)
$$

in which debt and equity values are, respectively, given by

$$
\begin{aligned}
d(x, k, s)= & (s / r)\left(1-\left(x / x_{d}(k)\right)^{\vartheta}\right) \\
& +\min \left[(1-\alpha) A\left(x_{d}(k), k\right), P\right]\left(x / x_{d}(k)\right)^{\vartheta}
\end{aligned}
$$

and

$$
\begin{aligned}
e(x, k, s)= & \Pi(x, k, s)-\Pi\left(x_{d}(k), k, s\right)\left(x / x_{d}(k)\right) \\
& +\max \left[(1-\alpha) A\left(x_{d}(k), k\right)-P, 0\right]\left(x / x_{d}(k)\right),
\end{aligned}
$$

where $\vartheta$ is defined as in Proposition 1 , and

$$
\Pi\left(x_{t}, k, s\right)=(1-\tau) \mathbb{E}^{x_{t}}\left[\int_{t}^{\infty} \mathrm{e}^{-r(u-t)}\left(\pi\left(x_{u}, k\right)-s\right) \mathrm{d} u\right] .
$$

Proof. See Appendix A.

Proposition 2 shows that the values of corporate securities depend on firm and industry characteristics. The latter are represented by the level and the instantaneous drift and volatility of the demand shift parameter. The size of the firm, its profit function, and its continuation value account for firm specificity. Eq. (19) also shows that, for a given coupon payment $s$, the value of corporate debt is strictly increasing in the liquidation value of the firm, defined as the 
abandonment value of the firm net of bankruptcy costs. Because credit spreads on corporate debt are defined by $C S(s)=(s / d(x, k, s))-r$, the above argument implies the following result.

Proposition 4. When bond covenants prevent the firm from adjusting its production capacity, higher asset liquidity results in lower credit spreads on corporate debt and higher leverage ratios.

To characterize the default threshold selected by shareholders, the abandonment value of the firm must be specified further. Following Mello and Parsons (1992), I assume that, after default, the new owners of the firm continue to employ the assets in their current use. Specifically, the abandonment value of levered the firm, $A\left(x_{d}(k), k\right)$, equals the unlevered value of the firm's assets:

$$
A\left(x_{d}(k), k\right)=\Pi\left(x_{d}(k), k, 0\right)-\left(\Pi\left(x_{a}(k), k, 0\right)-L\right)\left(x_{d}(k) / x_{a}(k)\right)^{\vartheta},
$$

in which $L \geqslant 0$ accounts for the abandonment value of unlevered assets and $x_{a}(k)$ is the abandonment threshold that maximizes the value of the unlevered firm. The first term of the right-hand side of Eq. (22) is the value of a perpetual entitlement to the flow of payments generated by the firm's assets when the firm is unlevered. The second term is the change occurring in asset value upon default multiplied by the Arrow-Debreu price of this event.

The abandonment value of the firm described by Eq. (22) has important implications for the payoffs to claimholders upon default. In particular, it implies that, under a stock-based definition of default, shareholders get nothing upon default if absolute priority is enforced. To see this, note that the par value of debt at the time of issuance, $P$, must be larger or equal to its face value, $d(x, k, s)$. If it were not the case, it would be optimal for shareholders to default immediately after debt issuance. As as result, if upon default

$$
e\left(x_{d}(k), k, s\right)=v\left(x_{d}(k), k, s\right)-d\left(x_{d}(k), k, s\right)=0,
$$

then it is also true that, for $\alpha \geqslant 0$,

$$
(1-\alpha) A\left(x_{d}(k), k\right)-P \leqslant v\left(x_{d}(k), k, s\right)-P \leqslant 0 .
$$

Therefore, as long as absolute priority is enforced, shareholders do not internalize the liquidation value of the firm in their default decision and the 
default threshold $x_{d}(k)$ satisfies the smooth-pasting condition ${ }^{9}$

$$
\left.\frac{\partial e(x, k, s)}{\partial x}\right|_{x=x_{d}(k)}=0 .
$$

Because equity value in a levered firm $(e(x, k, s))$ differs from the value of the unlevered firm $\left(v_{a}\left(x, k_{a}\right)\right)$, this default triggering condition differs from the abandonment condition described by Eq. (10). Therefore, shareholders do not select ex post the default threshold that maximizes firm value.

The following Proposition gives the value of corporate securities and specifies the default policy that maximizes the value of equity under this specification.

Proposition 5. Assume that the abandonment value of the firm equals the unlevered value of the firm's assets. Then, debt and equity values are, respectively, given by

$$
d(x, k, s)=(s / r)\left(1-\left(x / x_{d}(k)\right)^{\vartheta}\right)+(1-\alpha) A\left(x_{d}(k), k\right)\left(x / x_{d}(k)\right)^{\vartheta},
$$

and

$$
e(x, k, s)=\Pi(x, k, s)-\Pi\left(x_{d}(k), k, s\right)\left(x / x_{d}(k)\right)^{\vartheta} .
$$

The default threshold that maximizes the value of shareholders' claim is defined by

$$
x_{d}(k)=\left[\frac{\vartheta}{\vartheta-\gamma} \frac{c+s}{r a k^{1-\gamma}}\left(r-\gamma \mu-\gamma(\gamma-1) \frac{\sigma^{2}}{2}\right)\right]^{1 / \gamma} .
$$

The abandonment value described in Eq. (22) implies that it is optimal for shareholders to exercise their option to default when the firm has negative economic net worth. Eq. (28) reveals that this occurs when the present value of the payoffs to be received is equal to the opportunity costs of remaining active multiplied by a factor that represents the value of waiting to default. This policy implies that shareholders inject capital in the firm whenever the firm is insolvent on a flow basis but solvent on a stock basis. (I show in Section 3 that the possibility of selling assets allows the borrower to rely on another source of funds to finance continued operation of the firm's assets.)

Finally, note that $e(x, k, s)$ accounts for the value of equity ex post whereas $v(x, k, s)$ represents its value ex ante (at the time of debt issuance). As a result, although the default threshold is selected (ex post) to maximize $e(x, k, s)$, the

\footnotetext{
${ }^{9}$ In general, the abandonment value of the firm's assets is determined by the value of these assets if they were operated by the firm's competitors. Eq. (22) reflects the implicit assumption that these competitors use a production technology that can be described by Eq. (1). However, some of the firm's competitors may have access to different technologies, allowing them for example to generate higher cash flows when the state variable is low. In that case, the payoff to shareholders upon default can be strictly positive.
} 
amount of debt that the firm issues (ex ante) maximizes $v(x, k, s)$. Specifically, optimal leverage is defined at the time of debt issuance by

$$
s^{*}=\arg \max _{s \in \mathbb{R}_{+}} v(x, k, s) .
$$

\subsection{Comparative statics}

Simulation results reported in Table 2 are based on Proposition $5 .^{10}$ In this table, credit spreads are measured at optimal leverage. The net tax benefit of debt is given by

$$
N T B=\frac{v\left(x, k, s^{*}\right)-v(x, k, 0)}{v(x, k, 0)} .
$$

Parameter values for the base case environment are set as in Section 2. I further assume that bankruptcy costs are given by $\alpha=20 \%$.

Simulation results show that optimal leverage and credit spreads depend on firm and industry characteristics. In particular, Table 2 reveals that asset productivity $(1-\gamma)$ and demand uncertainty $(\sigma)$ have a large impact on firm value, leverage ratios and credit spreads. The higher the productivity of the firm's assets, the lower the probability of default and, therefore, the higher the value of corporate debt. By contrast, the larger demand uncertainty, the higher the interest rate the borrower has to pay and the lower the gains associated with debt financing. I show below that these two factors also affect the firm's decisions regarding the pledging of collateral.

Simulation results also show that higher liquidity (i.e., a higher liquidation value of the firm's assets) results in higher optimal leverage and lower spreads. An increase of $A(x, k)=L$ from 50 to 100 raises the optimal leverage from $67.2 \%$ to $67.6 \%$ and decreases the credit spread from 56 basis points to 45 basis points.

Finally, Table 2 reveals that the model developed in this section suffers from the two main failures of contingent claims models of the firm. First, for any set of input parameter values, predicted leverage ratios are far in excess of current practice. Second, predicted spreads are low given the leverage ratios generated by the model. In Section 4, I show that allowing the firm to adjust its production capacity to economic conditions lowers leverage ratios and, at the same time, increases corporate spreads.

\footnotetext{
${ }^{10}$ The value of the unlevered firm given in Table 2 does not account for the value of the contraction options because firm size is fixed throughout the section. Tables 1,3 and 4 give the value of the unlevered firm when the value of these options is incorporated. The value of the unlevered firm is then given by $v_{a}(x, k)$ derived in Proposition 1 .
} 
Table 2

Table 2 reports comparative statics associated with Proposition 5. Credit spreads are defined by $C S(s)=(s / d(x, k, s))-r$ and are measured at optimal leverage. The net tax benefit of debt is given by $N T B=\left[v\left(x, k, s^{*}\right)-v(x, k, 0)\right] / v(x, k, 0)$. The base case parameters are set as follows: The riskless interest rate $r=6 \%$, the size of the firm $k=100$, the productivity of assets in place $\gamma=0.53$, the tax advantage of debt $\tau=15 \%$, liquidation $\operatorname{costs} \alpha=20 \%$, and the liquidation value of unlevered assets $L=k l$. The profit function is further characterized by $\mu=0.01, \sigma=0.2$, $a=1, c=1$, and $x_{0}=1$.

\begin{tabular}{lccccc}
\hline $\begin{array}{l}\text { Input } \\
\text { parameter } \\
\text { values }\end{array}$ & $\begin{array}{c}\text { Optimal } \\
\text { leverage } \\
(\%)\end{array}$ & $\begin{array}{c}\text { Levered } \\
\text { firm value } \\
v\left(x, k, s^{*}\right)\end{array}$ & $\begin{array}{c}\text { Unlevered } \\
\text { firm value } \\
v(x, k, 0)\end{array}$ & $\begin{array}{c}\text { Net tax } \\
\text { benefit } \\
(\%)\end{array}$ & $\begin{array}{c}\text { Credit } \\
\text { spread } \\
(\text { bps })\end{array}$ \\
\hline Base & 67.6 & 120.8 & 109.9 & 9.9 & 45 \\
$\gamma=0.50$ & 68.2 & 139.5 & 127.5 & 9.4 & 46 \\
$\gamma=0.56$ & 67.3 & 105.0 & 94.6 & 11.0 & 39 \\
$\sigma=0.15$ & 72.0 & 126.0 & 114.6 & 10.0 & 33 \\
$\sigma=0.25$ & 64.7 & 115.9 & 104.5 & 10.0 & 52 \\
$\alpha=0$ & 81.2 & 127.5 & 109.9 & 16.0 & 41 \\
$\alpha=0.6$ & 53.1 & 114.7 & 109.9 & 4.4 & 69 \\
$L=0.5 \mathrm{kl}$ & 67.2 & 119.4 & 109.9 & 8.6 & 56 \\
$L=0.75 \mathrm{kl}$ & 67.4 & 119.9 & 109.9 & 9.1 & 52 \\
\hline
\end{tabular}

\section{Capacity adjustments and capital structure}

\subsection{Overview}

In Section 3, I have presented a model of asset prices in which firm size is fixed: Changes in the demand for the good produced by the firm do not induce any adjustment in the firm's production capacity. An example of this case is a situation in which bond covenants prevent the firm from selling its assets. When the bond indenture includes such debt covenants, assets in place represent a fair collateral and asset liquidity increases optimal leverage and reduces credit spreads. However, as noticed by Smith and Warner (1979b), "one cost associated with flat prohibitions on the sale of particular assets rises from the fact that the firm is not permitted to divest itself of those assets whose value to others is greater than the value to itself".

I now relax the assumption that firm size is fixed until the closure time and instead allow the firm to adjust its production capacity over its entire life. However, following Smith and Warner (1979b, paragraph 2.1.2), I consider that the debt contract requires that the firm, "not otherwise than in the ordinary course of business, sell, lease, transfer, or otherwise dispose of any 
substantial part of its properties and assets". Therefore, although I allow downward capacity adjustments to fit the demand evolution in the firm's product market, I assume that bond covenants prevent the manager from selling the firm's assets to appropriate firm value just before declaring bankruptcy. ${ }^{11}$ Here again, if default occurs, bondholders receive the abandonment value of the firm less default costs. Finally, I do not consider upward capacity adjustments since I am interested in the impact of possible asset sales on optimal capital structure and firm value in comparison with the benchmark model in which firm size is fixed. ${ }^{12}$

This section derives two main results. First, I show that ceteris paribus the possibility of selling assets increases equity value and reduces debt value. Second, I demonstrate that, depending on firm and industry characteristics, imposing restrictions on the disposition of assets may reduce firm value.

An outline for these implications is as follows. The possibility of selling assets provides flexibility to the borrower by allowing it to reduce firm size when there is an economic downturn. Although these capacity reductions are irreversible, they raise equity value for two reasons. First, asset sales allow the firm to increase dividend payments when it is solvent. Second, they allow the firm to finance continued operation of its remaining assets without requiring capital injections by shareholders when the firm is solvent on a stock basis but insolvent on a flow basis. By contrast, because they decrease the liquidation value of the firm and change the timing of default, asset sales reduce the value of bondholders' claim. In a rational expectations model, bondholders recognize the adverse borrower behavior and credit spreads adjust to yield a normal compensation. As a result, the firm substitutes equity for debt, thereby reducing leverage.

The effect of asset sales on firm value results from a trade-off between the decrease in debt value and the value of the operating flexibility provided to the firm. As a consequence, it depends on firm and industry characteristics such as asset productivity and demand uncertainty.

\footnotetext{
${ }^{11}$ When an immediate piecewise liquidation of the firm just before default is possible, securing the debt contract gives bondholders title to the pledged assets until the bonds are paid in full (see Section 5). See also Smith and Warner (1979a, b) and Johnson and Stulz (1985).

${ }^{12}$ See Abel and Eberly (1996) for an analysis of capacity choice under uncertainty. When upward capacity adjustments are allowed, the operating flexibility of the firm is larger. As a result, the expected present value of the cash flows that claimholders will receive is more important. Because bondholders have fixed income rights, this increase in operating flexibility has a limited impact on the value of their claims (the only difference coming from a larger liquidation value of the firm induced by a change in the default policy maximizing shareholders' wealth). In contrast, the value of equity raises significantly, thereby strengthening the effects of asset liquidity on leverage decisions and firm value.
} 


\subsection{Ex post capacity adjustments}

Consider that the firm has a right to adjust its production capacity to economic conditions and denote the constant selling price of assets by $l$. The level of this selling price represents a second measure of liquidity for the firm's asset, i.e., the ease with which they can be sold on a secondary market over the entire life of the firm.

In order to determine the effects of capacity adjustments on the values of corporate securities, the path of firm size through time must be characterized. Because management acts in the best interests of shareholders, this path depends on the contraction policy that maximizes equity value. The optimal contraction policy for shareholders is to sell assets whenever their marginal valuation of capital is lower than the resale value of assets. Thus, depending on the sale price $l$, it may be optimal to sell part of the firm's assets before $x_{d}(k)$ is reached. In this light, one can think of equity value as comprising the expected present value of the cash flow to be received plus a continuum of options to reduce capacity and the option to exit the industry.

I denote the value of equity in this new setting by $e_{l}(x, k, s)$ and firm size upon closure by $k_{l}$ (determined endogenously below). Since the firm can adjust capacity before declaring default, equity value satisfies

$$
\begin{aligned}
e_{l}(x, k, s) & =(1-\tau) \mathbb{E}^{x_{0}}\left[\int_{0}^{+\infty} \mathrm{e}^{-r u}\left(\pi\left(x_{u}, k\right)-s\right) \mathrm{d} u\right] \\
& -(1-\tau) \mathbb{E}^{x_{0}}\left[\int_{T_{x_{d}\left(k_{l}\right)}^{+\infty}} \mathrm{e}^{-r u}\left(\pi\left(x_{u}, k\right)-s\right) \mathrm{d} u\right] \\
& +\max \left[(1-\alpha) A\left(x_{d}\left(k_{l}\right), k_{l}\right)-P, 0\right] \mathbb{E}^{x_{0}}\left[\mathrm{e}^{\left.-r T_{x_{d}\left(k_{l}\right)}\right]}\right] \\
& +\int_{k}^{k_{l}}\left(l \mathbb{E}^{x_{0}}\left[\mathrm{e}^{-r T_{x_{l}(v)}}\right]-(1-\tau) \mathbb{E}^{x_{0}}\left[\int_{T_{x_{l}(k)}}^{+\infty} \mathrm{e}^{-r u} \pi_{\kappa}\left(x_{u}, \kappa\right) \mathrm{d} u\right]\right) \mathrm{d} \kappa .
\end{aligned}
$$

In Eq. (31), the first term of the right-hand side is the unlimited liability value of the payoffs to be received by shareholders. The second and third terms represent the value of the option to exit the industry. The fourth term accounts for the value of the options to reduce capacity. Eq. (31) suggests that the proceeds from asset sales accrue to shareholders. However, because shareholders only have residual income rights, these proceeds are used by the firm to pay debt service and cover operating losses when the firm is insolvent on a flow basis but solvent on a stock basis. 
For any given current production capacity $\kappa, \kappa \in\left[k_{l}, k\right]$, the optimal sales curve $x_{l}(\kappa)$ defining the contraction policy satisfies the high-contact condition

$$
\left.\frac{\partial^{2} e_{l}(x, k, s)}{\partial k \partial x}\right|_{x=x_{l}(\kappa)}=0 .
$$

This condition is similar to Eq. (7). However, the contraction policy that maximizes equity value differs from the one that maximizes the value of the unlevered firm because firm size upon closure depends on the debt service selected by shareholders. Solving this equation yields

$$
x_{l}(\kappa)=\left(\frac{\vartheta}{\vartheta-\gamma} \frac{l\left(r-\mu \gamma-\gamma(\gamma-1) \sigma^{2} / 2\right)}{(1-\gamma)(1-\tau) a}\right)^{1 / \gamma} \kappa .
$$

The contraction policy described by Eq. (33) shows that it is optimal to reduce capacity when the profit generated by the marginal capital unit equals its adjusted selling price $(\vartheta /(\vartheta-\gamma)) l$. A simple analogy with option pricing theory reveals that this adjustment in the selling price accounts for the difference between the exercise boundary of the option allowing the firm to adjust capacity and the selling price of assets (the strike price). As usual for American options, the firm should not exercise its real options as soon as they are in the money.

Also, when Eq. (33) obtains and the firm is in distress, asset sales are in the best interest of the firm since the net sale proceeds exceed the present value of the cash flows from continued operation of the marginal capital unit. Asset sales represent the cheapest source of funds for the firm and are used to finance continued operation of the firm's remaining assets (see Lang et al., 1995, for empirical evidence).

Finally, consistent with the empirical study by Maksimovic and Phillips (1998), Eq. (33) relates asset sales to demand conditions, represented by the parameters determining the path of the demand shock, and to firm characteristics, such as asset productivity and current firm size.

\subsection{Valuation of corporate securities}

When the initial production capacity $k$ is larger than $k_{l}$, asset sales affect debt value because they reduce firm size upon default and increase the probability of default. Since firm size upon default and the default probability depend on observable factors, bondholders can anticipate the reduction in the value of their claims stemming from asset sales. As a result, for any given coupon payment, the payoffs to claimholders upon closure no longer depend on current firm size but on $k_{l}$. This leads to the following proposition.

Proposition 6. Assume that input parameter values are such that $k>k_{l}$. When the firm is endowed with the possibility of selling assets and its instantaneous 
profit function is described by Eqs. (1) and (2), the value of the firm for a fixed flow of coupon payments satisfies

$$
v_{l}(x, k, s)=e_{l}(x, k, s)+d_{l}(x, k, s),
$$

where the values of corporate debt and equity are respectively given by

$$
\begin{aligned}
d_{l}(x, k, s)= & (s / r)\left(1-\left(x / x_{d}\left(k_{l}\right)\right)^{\vartheta}\right) \\
& +\min \left[(1-\alpha) A\left(x_{d}\left(k_{l}\right), k_{l}\right), P\right]\left(x / x_{d}\left(k_{l}\right)\right)^{\vartheta}
\end{aligned}
$$

and

$$
\begin{aligned}
e_{l}(x, k, s)= & \Pi(x, k, s)+p\left(k, k_{l}\right)-\Pi\left(x_{d}\left(k_{l}\right), k_{l}, s\right)\left(x / x_{d}\left(k_{l}\right)\right)^{\vartheta} \\
& +\max \left[(1-\alpha) A\left(x_{d}\left(k_{l}\right), k_{l}\right)-P, 0\right]\left(x / x_{d}\left(k_{l}\right)\right)^{\vartheta} .
\end{aligned}
$$

In Eq. (36), p $\left(k, k_{l}\right)$ accounts for the value of the options to reduce firm size from $k$ to $k_{l}$ and is given by

$$
p\left(k, k_{l}\right)=\frac{\gamma l}{(\gamma-\vartheta)(1-\vartheta)}\left(k\left(x / x_{l}(k)\right)^{\vartheta}-k_{l}\left(x / x_{l}\left(k_{l}\right)\right)^{\vartheta}\right) .
$$

The contraction thresholds satisfy Eq. (33). Firm size upon default is defined by $x_{d}\left(k_{l}\right)=x_{l}\left(k_{l}\right)$. When input parameter values are such that $k \leqslant k_{l}$, the values of debt and equity are defined as in Proposition 3.

Proof. See Appendix A.

Eq. (36) from Proposition 6 shows that the strategy space open to the borrower by the possibility of selling assets increases equity value in comparison with Eq. (21). As mentioned earlier, asset sales allow the borrower (1) to increase dividend payments when the firm is solvent and (2) to finance continued operation of the firm's assets without requiring capital injections by shareholders when it is in financial distress. By contrast, Eq. (35) shows that asset sales reduce debt value in comparison with Eq. (20) by (1) increasing the default probability and (2) decreasing firm size upon default. ${ }^{13}$ Thus, when the borrower can adjust its production capacity to economic conditions, optimal leverage is reduced.

In order to characterize the default policy that maximizes the value of equity, the abandonment value of the firm must be specified further. Following Section 3 , I assume that the abandonment value of the firm is given by the unlevered value of the firm's assets. Under this assumption, the default threshold that

\footnotetext{
${ }^{13}$ The present value of one dollar contingent on default raises from $\left(x / x_{d}(k)\right)^{\vartheta}$ to $\left(x / x_{d}\left(k_{l}\right)\right)^{9}$ and the abandonment value of the firm's assets decreases from $A\left(x_{d}(k), k\right)$ to $A\left(x_{d}\left(k_{l}\right), k_{l}\right)$.
} 
maximizes the value of equity satisfies

$$
\left.\frac{\partial e_{l}\left(x, k_{l}, s\right)}{\partial x}\right|_{x=x_{d}\left(k_{l}\right)}=0
$$

and the following results.

Proposition 7. Assume that the abandonment value of the firm equals the unlevered value of the firm's assets. Then, the values of corporate debt and equity satisfy respectively

$$
d_{l}(x, k, s)=(s / r)\left(1-\left(x / x_{d}\left(k_{l}\right)\right)^{\vartheta}\right)+(1-\alpha) A\left(x_{d}\left(k_{l}\right), k_{l}\right)\left(x / x_{d}\left(k_{l}\right)\right)^{\vartheta}
$$

and

$$
e_{l}(x, k, s)=\Pi(x, k, s)+p\left(k, k_{l}\right)-\Pi\left(x_{d}\left(k_{l}\right), k_{l}, s\right)\left(x / x_{d}\left(k_{l}\right)\right)^{\vartheta} .
$$

The default threshold selected by shareholders is given by

$$
x_{d}\left(k_{l}\right)=\left[\frac{\vartheta}{\vartheta-\gamma} \frac{c+s}{r a\left(k_{l}\right)^{1-\gamma}}\left(r-\gamma \mu-\gamma(\gamma-1) \frac{\sigma^{2}}{2}\right)\right]^{1 / \gamma} .
$$

Eq. (41) from Proposition 7 can also be written as

$$
\frac{a\left(x_{d}\left(k_{l}\right)\right)^{\gamma}\left(k_{l}\right)^{1-\gamma}}{r-\gamma \mu-\gamma(\gamma-1) \sigma^{2} / 2}=\frac{\vartheta}{\vartheta-\gamma} \frac{c+s}{r} .
$$

The left-hand side of Eq. (42) is the expected present value of the cash flows from the firm's assets at the default time. The right-hand side is the opportunity cost of remaining active.

For any given production capacity $\kappa, \kappa \in\left[k_{l}, k\right]$, the level of the demand shift parameter that determines flow based insolvency is defined by

$$
x_{f}(\kappa)=\left[\frac{c+s}{a \kappa^{1-\gamma}}\right]^{1 / \gamma} \gg x_{d}\left(k_{l}\right) .
$$

As mentioned earlier, although the contraction policy defined in Eq. (33) maximizes the value of equity, the proceeds from asset sales are reinjected by shareholders in the firm to service the debt obligations whenever the firm is insolvent on a flow basis but solvent on a stock basis.

Propositions 6 and 7 show that the impact of asset sales on the values of corporate securities depends on the strategy space open to the borrower by asset liquidity. Bond covenants usually prevent the borrower from liquidating the firm's assets just before defaulting. Therefore, management can only adjust capacity when the sales curve is higher than the default threshold, i.e., when $x_{l}(k) \geqslant x_{d}(k)$. Using Eqs. (33) and (41), the following results. 
Proposition 8. The possibility of selling assets expands the strategy space open to the borrower and reduces the value of corporate debt whenever current firm size is larger than firm size upon default $k_{l}$. When the abandonment value of the firm equals the unlevered value of the firm's assets, firm size upon default satisfies

$$
k_{l} l=(1-\gamma)(1-\tau) \frac{c+s}{r} .
$$

Propositions 2, 7 and 8 show that when $(1-\tau) s=r L$, the operating and contraction policies of the levered firm are identical to those of the unlevered firm. When $(1-\tau) s>r L, k_{l}>k_{a}$ and $x_{d}\left(k_{l}\right)>x_{a}\left(k_{a}\right)$ result and leverage induces overinvestment in unproductive assets and early exit. When $(1-\tau) s<r L$, the reverse is true: Leverage induces underinvestment in the firm's assets $\left(k_{l}<k_{a}\right)$ and late exit $\left(x_{d}\left(k_{l}\right)<x_{a}\left(k_{a}\right)\right)$. Also, observe that the liquidation value of the firm does not appear directly in the equation that determines firm size upon default, $k_{l}$. However, optimal leverage $s^{*}$ depends on this liquidation value and so does firm size upon default.

\subsection{Comparative statics}

Simulation results reported in Table 3 are based on Propositions 7 and 8 . These results underline the impact of asset liquidity on the values of corporate securities and the firm's financing decisions. Table 3 shows that asset liquidity has a significant impact on the capital structure choices of the firm. In the base case environment, for example, the possibility of selling assets reduces the optimal leverage ratio from $67.6 \%$ to $29.4 \%$.

Although optimal leverage is lower, credit spreads on corporate debt are higher when the firm can sell assets before declaring bankruptcy. As shown in Proposition 6, asset sales reduce debt value. In a rational expectations model, bondholders anticipate the opportunistic behavior of shareholders and the level of credit spreads reflects the associated wealth extraction. The increase in credit spreads is more important when the firm does not adjust its financing policy. In the base case environment for example, credit spreads are boosted up to 227 basis points (not shown in the table).

Section 3 shows that when firm size is fixed, an increase in the liquidation value of the firm's assets increases optimal leverage and reduces credit spreads (see Table 2). This effects also shows up in Table 3 where increasing $L$ from $0.5 k_{l} l$ to $k_{l} l$ increases optimal leverage from $28.2 \%$ to $29.4 \%$ and reduces the credit spread from 86 basis points to 84 basis points. An increase in the selling price, $l$, works in the opposite direction, decreasing the optimal leverage and increasing spreads. This shows up in the bottom of Table 3 , where an increase of $l$ from 0.8 to 1.2 decreases the optimal leverage from $40.5 \%$ to $21 \%$ and increases the credit spread from 80 to 86 basis points. 
Table 3

Table 3 reports comparative statics associated with Propositions 7 and 8 . Credit spreads are defined by $C S(s)=(s / d(x, k, s))-r$ and are measured at optimal leverage. The net tax benefit of debt is given by $N T B=\left[v_{l}\left(x, k, s^{*}\right)-v_{a}(x, k)\right] / v_{a}(x, k)$. The base case parameters are set as follows: The riskless interest rate $r=6 \%$, the initial size of the firm $k=100$, the productivity of assets in place $\gamma=0.53$, the tax advantage of debt $\tau=15 \%$, liquidation costs $\alpha=20 \%$, the liquidation value of unlevered assets $L=k_{l} l$, and the sale price of assets in place $l=1$. The profit function is further characterized by $\mu=0.01, \sigma=0.2, a=1, c=1$, and $x_{0}=1$.

\begin{tabular}{lcccccc}
\hline $\begin{array}{l}\text { Input } \\
\text { parameter } \\
\text { values }\end{array}$ & $\begin{array}{c}\text { Optimal } \\
\text { leverage } \\
(\%)\end{array}$ & $\begin{array}{c}\text { Levered } \\
\text { firm value } \\
v_{l}\left(x, k, s^{*}\right)\end{array}$ & $\begin{array}{c}\text { Unlevered } \\
\text { firm value } \\
v_{a}(x, k)\end{array}$ & $\begin{array}{c}\text { Net tax } \\
\text { benefit } \\
(\%)\end{array}$ & $\begin{array}{c}\text { Credit } \\
\text { spread } \\
(\mathrm{bps})\end{array}$ & $\begin{array}{c}\text { Closure } \\
\text { size } \\
k_{l}\end{array}$ \\
\hline Base & 29.4 & 134.2 & 130.8 & 2.6 & 84 & 25 \\
$\gamma=0.50$ & 37.5 & 144.6 & 139.7 & 3.5 & 76 & 33 \\
$\gamma=0.56$ & 22.5 & 131.1 & 128.7 & 1.9 & 92 & 19 \\
$\sigma=0.15$ & 33.6 & 139.7 & 134.9 & 3.6 & 57 & 27 \\
$\sigma=0.25$ & 25.4 & 130.8 & 128.5 & 1.8 & 109 & 22 \\
$\alpha=0$ & 42.0 & 136.2 & 130.8 & 4.1 & 103 & 33 \\
$\alpha=0.6$ & 18.6 & 132.6 & 130.8 & 1.4 & 73 & 18 \\
$l=0.8$ & 40.5 & 123.4 & 118.9 & 3.8 & 80 & 37 \\
$l=1.2$ & 21 & 154.2 & 151.5 & 1.8 & 86 & 18 \\
$L=0.5 k_{l} l$ & 28.2 & 133.8 & 130.5 & 2.5 & 86 & 24 \\
$L=0.75 k_{l} l$ & 28.7 & 134.0 & 130.6 & 2.5 & 85 & 24 \\
\hline
\end{tabular}

The net effect of asset liquidity on firm value results from a trade-off between the increase in equity value and the decrease in debt value. As a result, it depends on firm and industry characteristics such as the productivity of assets in place or demand uncertainty. Therefore, contrary to standard structural models of the levered firm (see, e.g., Leland, 1994), the model presented above predicts that restrictions imposed on the disposition of assets do not always increase firm value. ${ }^{14}$ In particular, when the productivity of assets in place $(1-\gamma)$ is low, capacity adjustments are more likely to be optimal and, hence, pledging assets results in overinvestment in unproductive assets. For higher levels of asset productivity, the net effect on firm value of restrictions on the disposition of assets is negatively related to demand uncertainty and firm size (i.e. the strategy space open to the borrower) and positively related to the level of interest rates and the liquidation value of the firm. Finally, Table 3 also

\footnotetext{
${ }^{14}$ In these models, a lower level of asset sales increases firm value because a higher leverage ratio can be supported when more assets remain in the firm. As a result, Leland finds that "ex ante shareholders (as well as bondholders) benefit from a covenant that prevents the firm from selling assets to meet coupon payments".
} 
reveals that, because a higher sale price for assets reduces firm size upon closure, shocks to asset liquidity and asset productivity have opposite effects on the values of corporate securities.

\section{Secured debt and optimal capital structure}

\subsection{Overview}

Section 4 shows that, when the bond indenture does not include covenants restricting the disposition of assets, asset liquidity reduces the value of bondholders' claim. As a result, asset liquidity increases the cost of borrowing by increasing transaction costs imposed on lenders. When firm and industry characteristics are such that the value of the operating flexibility associated with asset liquidity is larger than the reduction in debt value, asset liquidity increases firm value. When they are such that the opposite is true, the firm will try to lessen these transaction costs by committing not to sell assets. It can do so credibly by securing the debt contract. ${ }^{15} \mathrm{~A}$ debt contract is said to be secured if the borrower pledges assets as security until the bonds are paid in full. When debt is secured, the firm cannot dispose of the pledged assets without bondholders' approval. ${ }^{16}$ Moreover, if the firm files for bankruptcy, secured creditors acquire title to the pledged assets prior to any other claimant.

This section shows that pledging part of the firm's assets as collateral to the debt contract by issuing secured debt increases firm value. This result is derived under the assumption that the pledge freezes the assets in their current use. The secured debt contract generally allows asset sales if the proceeds are used to pay off the loan. ${ }^{17}$ To simplify the analysis, I do not consider this possibility by assuming that partial repayments of the loan induce transaction costs that are high enough to destroy value. Allowing partial repayments of the loan prior to maturity would, however, strengthen the conclusion that it is optimal for the firm to pledge part of its assets. Indeed, partial repayments of the loan reduce both the default probability and wealth transfers from bondholders to shareholders. Therefore, they decrease the corporate spread and, hence, increase optimal leverage and firm value.

\footnotetext{
${ }^{15}$ Other contractual devices can achieve the same goal (see footnote $3 \mathrm{a}$ ). However, as noted by Smith and Warner (1979a) and Johnson and Stulz (1985), secured debt is not as expensive to monitor as other forms of bond covenants.

${ }^{16}$ Even if the pledged assets are sold by the borrower without bondholders' approval, the Uniform Commercial Code ensures that the security interest in the collateral continues after the sale. Therefore, the security provision lowers the price that other parties will pay for the firm's assets and, hence, limits asset sales and wealth transfers.

${ }^{17}$ See the sample covenant 3, American Bar Foundation (1971, p. 427).
} 
Secured debt reduces the interest rate the firm has to pay to bondholders in two ways. First, it prevents the firm from selling assets and thus reduces the default probability and preserves the liquidation value of the firm. Second, bankruptcy costs are reduced in the event of default because of lower enforcement costs. However, by securing the debt contract the firm also reduces its strategy space in terms of operating flexibility. As mentioned by Smith and Warner (1979b), "securing debt involves opportunity costs by restricting the firm from potentially profitable dispositions of collateral". In my framework, pledging assets as collateral (1) induces overinvestment in unproductive assets and (2) prevents the firm from financing continued operation of its assets by selling part of them when it is optimal to do so.

\subsection{Valuation of corporate securities}

I denote bankruptcy costs when $K$ capital units are pledged as collateral by $\alpha(K)$, with $\alpha(K) \geqslant 0$ and $\partial \alpha(K) / \partial K \leqslant 0$, and the present value of out of pocket costs associated with the security provision by $S$. These costs include the valuation of the collateral, additional bonding and monitoring expenses, required reports to debtholders, filing fees for administrative registration, and other administrative expenses.

According to Proposition 2, asset liquidity may result in asset sales so long as current firm size is larger than $k_{l}$. As a result, the contraction policy of the firm is affected by the decision of the firm regarding the pledging of assets whenever this decision involves more than $k_{l}$ capital units. When $K$ capital units are pledged as collateral to the debt contract, $K \in\left[k_{l}, k\right]$, the value of equity satisfies

$$
\begin{aligned}
& e_{K}(x, k, s)=(1-\tau) \mathbb{E}^{x_{0}}\left[\int_{0}^{T_{x_{d}\left(k_{l} \vee K\right)}} \mathrm{e}^{-r u}\left[\pi\left(x_{u}, k\right)-s\right] \mathrm{d} u\right] \\
& +\max \left[(1-\alpha(K)) A\left(x_{d}\left(K \vee k_{l}\right),\left(K \vee k_{l}\right)\right)-P, 0\right] \mathbb{E}^{x_{0}}\left[\mathrm{e}^{-r T_{x_{d}\left(K \vee k_{l}\right)}}\right] \\
& +\int_{k}^{k_{l} \vee K}\left(l \mathbb{E}^{x_{0}}\left[\mathrm{e}^{-r T_{x_{l}(v)}}\right]-(1-\tau) \mathbb{E}^{x_{0}}\left[\int_{T_{x_{l}(k)}}^{+\infty} \mathrm{e}^{-r u} \pi_{\kappa}\left(x_{u}, \kappa\right) \mathrm{d} u\right]\right) \mathrm{d} \kappa
\end{aligned}
$$

in which $k_{l} \vee K=\sup \left(k_{l}, K\right)$.

The following proposition results. 
Proposition 9. When the firm's instantaneous profit function is described by Eqs. (1) and (2) and $K$ units of capital are pledged as collateral to the debt contract, $K<k$, the value of the firm for a fixed flow of coupon payments $s$ satisfies

$$
v_{K}(x, k, s)=e_{K}(x, k, s)+d_{K}(x, k, s),
$$

where the values of corporate debt and equity are, respectively, given by

$$
\begin{aligned}
d_{K}(x, k, s) & =(s / r)\left(1-\left(x / x_{d}\left(K \vee k_{l}\right)\right)^{\vartheta}\right) \\
& +\min \left[(1-\alpha(K)) A\left(x_{d}\left(K \vee k_{l}\right), K \vee k_{l}\right), P\right]\left(x / x_{d}\left(K \vee k_{l}\right)\right)^{\vartheta}
\end{aligned}
$$

and

$$
\begin{aligned}
e_{K}(x, k, s)= & \Pi(x, k, s)+p\left(k, K \vee k_{l}\right) \\
& -\Pi\left(x_{d}\left(K \vee k_{l}\right), K \vee k_{l}, s\right)\left(x / x_{d}\left(K \vee k_{l}\right)\right)^{\vartheta} \\
& +\max \left[(1-\alpha(K)) A\left(x_{d}\left(K \vee k_{l}\right), K \vee k_{l}\right)-P, 0\right] \\
& \left(x / x_{d}\left(K \vee k_{l}\right)\right)^{\vartheta}-S .
\end{aligned}
$$

In Eq. (48), the term $p\left(k, K \vee k_{l}\right)$ accounts for the value of the options to reduce firm size from $k$ to $K \vee k_{l}$ and is given by

$$
p\left(k, K \vee k_{l}\right)=\frac{\gamma l}{(\gamma-\vartheta)(1-\vartheta)}\left(k\left(x / x_{l}(k)\right)^{\vartheta}-\left(K \vee k_{l}\right)\left(x / x_{l}\left(K \vee k_{l}\right)\right)^{\vartheta}\right) .
$$

When $K=k$, the values of debt and equity are defined as in Proposition 3.

Proof. See Appendix A.

Proposition 9 extends Propositions 3 and 6 to incorporate the firm's decision regarding the pledging of assets. When $K=k$, all the firm's assets are pledged as collateral to the debt contract and the firm cannot adjust its production capacity to economic conditions. Thus, if $\partial \alpha(K) / \partial K=0$ and $S=0$, Proposition 3 holds and debt and equity values respectively satisfy Eqs. (19) and (20). When $K \vee k_{l}=k_{l}, \partial \alpha(K) / \partial K=0$ and $S=0$, Proposition 6 holds and securing debt does not affect the investment policy of the firm (asset sales and default decision). Therefore, $v_{K}(x, k, s)=v_{l}(x, k, s)$ where $v_{l} \times$ $(x, k, s)$ is defined in Proposition 6. Finally, when $K \vee k_{l}=K$ and $S=0$, the values of debt and equity are given by Eqs. (35) and (36) with $k_{l}$ and $\alpha$ replaced by $K$ and $\alpha(K)$.

Proposition 9 also shows that the default and contraction policies selected by shareholders are affected by the pledge that prevents the firm from reducing capacity as soon as the production capacity reaches $K$. Thus, securing the debt 
contract changes firm value, optimal leverage and credit spreads. Denote the coupon payment that maximizes firm value when $K$ units of capital are pledged as collateral by $s_{K}^{*}$ and the coupon payment that maximizes firm value when the debt contract is unsecured by $s_{l}^{*}$. The following proposition results.

Proposition 10. When input parameter values are such that $k>k_{l}$ and the instantaneous profit function of the firm is described by Eqs. (1) and (2), it is optimal for shareholders to pledge $\kappa$ units of capital as collateral to the debt contract, $\kappa \in\left[k_{l}, k\right]$, if

$$
v^{\kappa}\left(x, k, s_{\kappa}^{*}\right) \geqslant v_{K}\left(x, k, s_{K}^{*}\right), \quad \forall K \in\left[k_{l}, k\right],
$$

and

$$
v^{\kappa}\left(x, k, s_{\kappa}^{*}\right)>v_{l}\left(x, k, s_{l}^{*}\right) .
$$

According to Proposition 10, it is optimal to issue secured debt only if doing so increases the present value of the cash flows that both bondholders and shareholders receive. Thus, to understand the decision of the firm regarding the pledging of collateral, the impact of the security provision on both the market values of corporate securities and shareholders' default decision must be determined. For doing so, the abandonment value of the firm must be specified further.

Proposition 11. Assume that the abandonment value of the firm equals the unlevered value of the firm's assets. The values of debt and equity, respectively, satisfy

$$
\begin{aligned}
d_{K}(x, k, s) & =\frac{s}{r}\left(1-\left(x / x_{d}\left(K \vee k_{l}\right)\right)^{\vartheta}\right) \\
& +(1-\alpha(K)) A\left(x_{d}\left(K \vee k_{l}\right), K \vee k_{l}\right)\left(x / x_{d}\left(K \vee k_{l}\right)\right)^{\vartheta}
\end{aligned}
$$

and

$$
\begin{aligned}
e_{K}(x, k, s) & =\Pi(x, k, s)+p\left(k, K \vee k_{l}\right) \\
& -\Pi\left(x_{d}\left(K \vee k_{l}\right), K \vee k_{l}, s\right)\left(x / x_{d}\left(K \vee k_{l}\right)\right)^{\vartheta}-S .
\end{aligned}
$$

The default threshold selected by shareholders depends on the size of the pledge and is given by

$$
x_{d}\left(K \vee k_{l}\right)=\left[\frac{\vartheta}{\vartheta-\gamma} \frac{c+s}{r a\left(K \vee k_{l}\right)^{1-\gamma}}\left(r-\gamma \mu-\gamma(\gamma-1) \frac{\sigma^{2}}{2}\right)\right]^{1 / \gamma} .
$$

Proposition 11 determines the impact of the security provision on asset values. Consider first corporate debt. Eq. (52) shows that the value of corporate debt is equal to its continuation value minus a default premium. This default premium depends on the default probability, bankruptcy costs, and firm size upon default. Eq. (54) reveals that pledging $K$ units of capital, with 
$K \geqslant k_{l}$, reduces the default probability by decreasing default threshold. Because the security provision also lowers bankruptcy costs and increases firm size upon closure by limiting the strategy space open to the borrower, we have the following result.

Proposition 12. Assume that there exists $\kappa \in\left[k_{l}, k\right]$, such that $v^{\kappa}\left(x, k, s_{\kappa}^{*}\right)$ satisfies (50) and (51). Pledging $\kappa$ units of capital by securing the debt contract reduces credit spreads on corporate debt and increases optimal leverage.

Consider next equity just after debt issuance. Eq. (53) reveals that securing the debt contract reduces its value in two ways. First, pledging assets alters the use of real resources and, hence, reduces the operating flexibility of the firm. Second, the security provision lessens equity value because it calls for expenditures over the life of the contract that are ultimately paid by the borrower. However, securing the debt contract increases the average lifetime of assets in place and thus reduces the default probability. At optimal leverage the first two effects dominate, resulting in a decrease of equity value.

\subsection{Comparative statics}

Table 4 displays simulation results associated with Proposition 11. In accordance with the above discussion, the security provision raises leverage ratios and reduces corporate spreads in comparison with Table 3. In particular, in the base case environment the security provision raises the optimal leverage ratio from $29.4 \%$ to $35 \%$ and, at the same time, reduces the corporate spread from 84 to 54 basis points, numbers that are consistent with what is observed in practice. When there are no costs of financial distress, the model predicts a net tax advantage to debt of $4.4 \%$, which compares well with the $4.3 \%$ found by Graham (2000). Also, as the price claimholders get from the firm's assets upon liquidation increases, the optimal size of the pledge increases. In particular, when this abandonment price exceeds by $50 \%$ the price the firm can get by selling its assets in separate pieces over its entire life, it is optimal for the firm to pledge most of its assets $(74 \%)$.

One can also observe that pledging part of the firm's assets as collateral to the debt contract always increases firm value. This finding is in accordance with recent empirical studies reporting that most firms tend to borrow on a secured basis (see e.g. Barclay and Smith, 1995). However, data in Table 4 along with Table 2 reveal that pledging all the firm's assets can result in a large decrease in firm value. As mentioned earlier, the security provision reduces not only the interest rate the firm has to pay to the lender but also the operating flexibility of the firm. In the base case environment, the decrease in firm value reaches about $11 \%$. When the productivity of assets in place is lower, the security provision induces more overinvestment in unproductive assets and the decrease in firm 
Table 4

Table 4 reports comparative statics with Propositions 11. Credit spreads are defined by $C S(s)=(s / d(x, k, s))-r$ and are measured at optimal leverage. The net tax benefit of debt is given by $N T B=\left[v_{K}\left(x, k, s^{*}\right)-v_{a}(x, k)\right] / v_{a}(x, k)$. The base case parameters are set as follows: The riskless interest rate $r=6 \%$, the initial size of the firm $k=100$, the productivity of assets in place $\gamma=0.53$, the tax advantage of debt $\tau=15 \%$, liquidation $\operatorname{costs} \alpha=20 \%$, the liquidation value of unlevered assets $L=k_{l} l$, and the sale price of assets in place $l=1$. The profit function is further characterized by $\mu=0.01, \sigma=0.2, a=1, c=1$, and $x_{0}=1$.

\begin{tabular}{lcccccc}
\hline $\begin{array}{l}\text { Input } \\
\text { parameter } \\
\text { values }\end{array}$ & $\begin{array}{c}\text { Optimal } \\
\text { leverage } \\
(\%)\end{array}$ & $\begin{array}{c}\text { Levered } \\
\text { firm value } \\
v_{K}\left(x, k, s^{*}\right)\end{array}$ & $\begin{array}{c}\text { Unlevered } \\
\text { firm value } \\
v_{a}(x, k)\end{array}$ & $\begin{array}{c}\text { Net tax } \\
\text { benefit } \\
(\%)\end{array}$ & $\begin{array}{c}\text { Credit } \\
\text { spread } \\
(b p s)\end{array}$ & $\begin{array}{c}\text { Optimal } \\
\text { pledge } \\
K^{*}\end{array}$ \\
\hline Base & 35.0 & 134.7 & 130.8 & 3.0 & 54 & 38 \\
$\gamma=0.50$ & 45.6 & 145.5 & 139.7 & 4.2 & 47 & 53 \\
$\gamma=0.56$ & 26.2 & 131.4 & 128.7 & 2.1 & 62 & 27 \\
$\sigma=0.15$ & 41.5 & 140.8 & 134.9 & 4.4 & 34 & 45 \\
$\sigma=0.25$ & 28.7 & 131.0 & 128.5 & 1.9 & 78 & 30 \\
$\alpha=0$ & 46.1 & 136.6 & 130.8 & 4.4 & 74 & 43 \\
$\alpha=0.6$ & 26.3 & 133.1 & 130.8 & 1.8 & 48 & 31 \\
$l=0.8$ & 47.8 & 124.1 & 118.9 & 4.4 & 52 & 56 \\
$l=1.2$ & 24.0 & 154.7 & 151.5 & 2.7 & 55 & 27 \\
$L=0.5 k_{l} l$ & 30.8 & 134.1 & 130.5 & 2.8 & 66 & 33 \\
$L=0.75 k_{l} l$ & 32.8 & 134.3 & 130.6 & 2.8 & 62 & 34 \\
\hline
\end{tabular}

value can reach 25\%. More generally, Table 4 shows that the optimal size of the pledge depends on firm and industry characteristics such as the productivity of assets in place, the marketability of the firm's assets, and demand uncertainty.

\section{Conclusion}

In this paper, I analyze the impact of asset liquidity on the values of corporate securities and the firm's financing decisions. I show when liquidity is measured by the liquidation value of the firm's assets, an increase in liquidity increases optimal leverage and decreases the corporate spread. When liquidity is measured by the selling price of assets over the entire life of the firm, asset liquidity reduces the value of corporate debt by expanding the strategy space open to the borrower. In a rational expectations model, bondholders anticipate the decrease in the value of their claims and credit spreads are increased.

The model can determine the extent to which pledging assets reduces the cost of debt financing and distorts the firm's operating policy. I identify two distinct sources for the increase in debt value. First, the security provision prevents the 
firm from selling assets and increases its value in liquidation. Second, pledging assets reduces the default probability. However, by altering the use of real resources, the security provision also limits the operating flexibility of the firm. The optimal pledge trades off these costs and benefits and, as a result, depends on firm and industry characteristics such as asset productivity and demand uncertainty. Finally, the analysis also reveals that asset liquidity and security provisions may help explain the leverage ratios and credit spreads observed in practice.

\section{Appendix A}

\section{A.1. Value of the unlevered firm}

The value of the unlevered firm is defined by

$$
\begin{aligned}
& v_{a}(x, k)=(1-\tau) \mathbb{E}^{x_{0}}\left[\int_{0}^{+\infty} \mathrm{e}^{-r u} \pi\left(x_{u}, k\right) \mathrm{d} u\right]+A\left(x_{a}\left(k_{a}\right), k_{a}\right) \mathbb{E}^{x_{0}}\left[\mathrm{e}^{-r T_{x_{a}\left(k_{a}\right)}}\right] \\
& -(1-\tau) \mathbb{E}^{x_{0}}\left[\int_{T_{x a(k a)}}^{+\infty} \mathrm{e}^{-r u} \pi\left(x_{u}, k_{a}\right) \mathrm{d} u\right] \\
& +\int_{k}^{k_{a}}\left(l \mathbb{E}^{x_{0}}\left[\mathrm{e}^{-r T_{x_{l}(k)}}\right]-(1-\tau) \mathbb{E}^{x_{0}}\left[\int_{T_{x_{l}(k)}}^{+\infty} \mathrm{e}^{-r u} \pi_{\kappa}\left(x_{u}, \kappa\right) \mathrm{d} u\right]\right) \mathrm{d} \kappa
\end{aligned}
$$

Because $\pi(., k, s)$ is a borel bounded function, I can use the strong Markov property of Ito diffusions (see Karatzas and Shreve, 1991, p. 82) to write the third integral as

$$
\mathbb{E}^{x_{0}}\left[\mathrm{e}^{-r T_{x_{a}\left(k_{a}\right)}}\right] \mathbb{E}^{x_{a}\left(k_{a}\right)}\left[\int_{0}^{+\infty} \mathrm{e}^{-r u} \pi\left(x_{u}, k\right) \mathrm{d} u\right] .
$$

The first factor is given by (see Karatzas and Shreve, 1991, p. 197)

$$
\mathbb{E}^{x_{0}}\left[\mathrm{e}^{-r T_{x_{a}\left(k_{a}\right)}}\right]=\left(x / x_{a}\left(k_{a}\right)\right)^{\vartheta} .
$$

As a result, the value of the unlevered firm reduces to

$$
\begin{aligned}
v_{a}(x, k)= & \Pi(x, k)+\left[A\left(x_{a}\left(k_{a}\right), k_{a}\right)-\Pi\left(x_{a}\left(k_{a}\right), k\right)\right]\left(x / x_{a}\left(k_{a}\right)\right)^{\vartheta} \\
& +\int_{k}^{k_{a}}\left(l \mathbb{E}^{x_{0}}\left[\mathrm{e}^{-r T_{x_{l}(k)}}\right]-(1-\tau) \mathbb{E}^{x_{0}}\left[\int_{T_{x_{l}(k)}}^{+\infty} \mathrm{e}^{-r u} \pi_{\kappa}\left(x_{u}, \kappa\right) \mathrm{d} u\right]\right) \mathrm{d} \kappa,
\end{aligned}
$$


with

$$
\begin{aligned}
\Pi(x, k) & =(1-\tau) \mathbb{E}^{x}\left[\int_{0}^{+\infty} \mathrm{e}^{-r u} \pi\left(x_{u}, k\right) \mathrm{d} u\right] \\
& =\frac{(1-\tau) a x^{\gamma} k^{1-\gamma}}{r-\mu \gamma-\left(\sigma^{2} / 2\right) \gamma(\gamma-1)}-(1-\tau) \frac{c}{r} .
\end{aligned}
$$

Consider next the value of the contraction options. $\pi_{y}(., \kappa)$ is a borel bounded function. Therefore, I can once again use the strong Markov property to write the value of the contraction options as

$$
\int_{k}^{k_{a}} \mathbb{E}^{x_{0}}\left[\mathrm{e}^{-r T_{x_{l}}(\kappa)}\right]\left(l-(1-\tau) \mathbb{E}^{x_{l}(\kappa)}\left[\int_{0}^{+\infty} \mathrm{e}^{-r u} \pi_{\kappa}\left(x_{u}, \kappa\right) \mathrm{d} u\right]\right) \mathrm{d} \kappa,
$$

which reduces to

$$
\int_{k}^{k_{a}}\left(\frac{x}{x_{l}(\kappa)}\right)^{\vartheta}\left(l-\Pi_{\kappa}\left(x_{l}(\kappa), \kappa\right)\right) \mathrm{d} \kappa .
$$

Because the selling price of assets does not depend on the state variable $x$, the optimal contraction policy is defined by

$$
\left.\frac{\partial^{2} v_{a}(x, \kappa)}{\partial \kappa \partial x}\right|_{x=x_{l}(\kappa)}=0,
$$

which yields

$$
x_{l}(\kappa)=\left(\frac{\vartheta}{\vartheta-\gamma} \frac{l\left(r-\mu \gamma-\gamma(\gamma-1) \sigma^{2} / 2 t\right)}{(1-\gamma)(1-\tau) a}\right)^{1 / \gamma} \kappa .
$$

Replacing $x_{l}(\kappa)$ by its expression in Eq. (A.7) gives

$$
v_{a}(x, k)=\Pi(x, k)+p\left(k, k_{a}\right)+\left[A\left(x_{a}\left(k_{a}\right), k_{a}\right)-\Pi\left(x_{a}\left(k_{a}\right), k_{a}\right)\right]\left(x / x_{a}\left(k_{a}\right)\right)^{\vartheta},
$$

in which

$$
p\left(k, k_{a}\right)=\frac{\gamma l}{(\gamma-\vartheta)(1-\vartheta)}\left(k\left(x / x_{l}(k)\right)^{\vartheta}-k_{a}\left(x / x_{l}\left(k_{a}\right)\right)^{\vartheta}\right) .
$$




\section{A.2. Fixed capacity and value of the levered firm}

When the firm's production capacity is fixed, the value of equity satisfies

$$
\begin{aligned}
e(x, k, s)= & (1-\tau) \mathbb{E}^{x_{0}}\left[\int_{0}^{T_{x_{d}(k)}} \mathrm{e}^{-r u}\left(\pi\left(x_{u}, k\right)-s\right) \mathrm{d} u\right] \\
& +\max \left[(1-\alpha) A\left(x_{d}(k), k\right)-P, 0\right] \mathbb{E}^{x_{0}}\left[\mathrm{e}^{-r T_{x_{d}(k)}}\right] .
\end{aligned}
$$

This equation is similar to Eq. (A.1) and its solution can be derived using the same methodology. The value of corporate debt is

$$
d(x, k, s)=\mathbb{E}^{x_{0}}\left[\int_{0}^{T_{x_{d}(k)}} \mathrm{e}^{-r u} s \mathrm{~d} u\right]+\min \left[(1-\alpha) A\left(x_{d}(k), k\right), P\right] \mathbb{E}^{x_{0}}\left[\mathrm{e}^{-r T_{x_{d}(k)}}\right] .
$$

The second term of the right-hand side of this equation has already been computed. The first term can be written

$$
\mathbb{E}^{x_{0}}\left[\int_{0}^{T_{x_{d}(k)}} \mathrm{e}^{-r u} s \mathrm{~d} u\right]=\left(1-\mathbb{E}^{x_{0}}\left[\mathrm{e}^{-r T_{x_{d}(k)}}\right]\right) \int_{0}^{+\infty} \mathrm{e}^{-r u} s \mathrm{~d} u .
$$

Finally, the optimal default threshold derived in Proposition 5 is obtained by solving the smooth-pasting condition

$$
\left.\frac{\partial e(x, k, s)}{\partial x}\right|_{x=x_{d}(k)}=0 .
$$

\section{A.3. Capacity adjustments and value of the levered firm}

When bond covenants do not prevent capacity adjustments, the value of equity is

$$
\begin{aligned}
e_{l}(x, k, s)= & (1-\tau) \mathbb{E}^{x_{0}} \int_{0}^{T_{x_{d}\left(k_{l}\right)}} \mathrm{e}^{-r u}\left[\pi\left(x_{u}, k\right)-s\right] \mathrm{d} u \\
& +\max \left[(1-\alpha) A\left(x_{d}\left(k_{l}\right), k_{l}\right)-P, 0\right] \mathbb{E}^{x_{0}}\left[\mathrm{e}^{\left.-r T_{x_{d}\left(k_{l}\right)}\right]}\right. \\
& +\int_{k}^{k_{l}}\left(l \mathbb{E}^{x_{0}} \mathrm{e}^{-r T_{x_{l}(v)}}-(1-\tau) \mathbb{E}^{x_{0}}\left[\int_{T_{x_{l}(k)}}^{+\infty} \mathrm{e}^{-r u} \pi_{\kappa}\left(x_{u}, \kappa\right) \mathrm{d} u\right]\right) \mathrm{d} \kappa .
\end{aligned}
$$


This equation is similar to Eq. (A.1) and its solution can be derived using the same methodology. The production capacity of the firm upon default can be determined as follows. The sales curve that maximizes equity value is described by a continuous function. This function is strictly increasing in the current production capacity of the firm [see Eq. (33)]. The default threshold is also described by a continuous function, which is strictly increasing in the current production capacity of the firm (see Proposition 7). The existence and uniqueness of firm size upon default results from the fact that we have $\partial x_{l}(k) / \partial k>\partial x_{d}(k) / \partial k$ and, for $k>k_{l}, x_{l}(k)>x_{d}(k)$. The production capacity of the firm upon default is then defined by $x_{l}\left(k_{l}\right)=x_{d}\left(k_{l}\right)$.

\section{A.4. Secured debt and value of the levered firm}

When $K$ units of capital are pledged as collateral to the debt contract, equity value is given by

$$
\begin{aligned}
e_{K}(x, k, s) & =(1-\tau) \mathbb{E}^{x_{0}} \int_{0}^{T_{x_{d}\left(k_{l} \vee K\right)}} \mathrm{e}^{-r u}\left[\pi\left(x_{u}, k\right)-s\right] \mathrm{d} u \\
& +\max \left[(1-\alpha(K)) A\left(x_{d}\left(K \vee k_{l}\right),\left(K \vee k_{l}\right)\right)-P, 0\right] \mathbb{E}^{x_{0}}\left[\mathrm{e}^{\left.-r T_{x_{d}\left(K \vee k_{l}\right)}\right)}\right] \\
& +\int_{k}^{k_{l} \vee K}\left[l \mathbb{E}^{x_{0}} \mathrm{e}^{-r T_{x_{l}(y)}}-(1-\tau) \mathbb{E}^{x_{0}} \int_{0}^{T_{x_{l}(y)}} \mathrm{e}^{-r u} \pi_{y}\left(x_{u}, y\right) \mathrm{d} u\right] \mathrm{d} y .
\end{aligned}
$$

This equation is similar to Eq. (A.1) and its solution can be derived using the same methodology.

\section{A.5. Productivity of assets in place}

The instantaneous profit function described by Eq. (1) approximates the case of a firm with a CRS Cobb-Douglas production technology and facing an isoelastic demand curve. Consider a firm that produces output according to the production function

$$
q=\lambda L^{\phi} k^{1-\phi}
$$

in which $L$ is labor, $\lambda$ is a productivity parameter, and $1<\phi<1$ represents the share of output going to labor. This firm pays a constant wage $w$ and sells its output at a price given by the inverse demand curve

$$
p=x^{1-\theta} q^{\theta-1},
$$


where $0<\theta<1$ and $1 /(\theta-1)$ is the price elasticity of demand. According to this specification, the share of profits going to capital depends on $\phi$ and $\theta$ through the following relation:

$$
1-\gamma=\frac{(1-\theta) \phi}{1-\theta \phi} .
$$

Labor's share of national income in U.S. postwar data has been relatively constant over time at $\phi=0.64$ despite the increase in real wages (see, e.g., Kydland and Prescott, 1982). If $\theta=0.5$, the productivity of assets in place is $1-\gamma \cong 0.47$.

\section{References}

Abel, A., Eberly, J., 1996. Optimal investment with costly reversibility. Review of Economic Studies 63, 581-593.

American Bar Foundation, 1971. Commentaries on Model Debenture Indenture Provisions 1965. Chicago, Illinois.

Barclay, M., Smith, C., 1995. The priority structure of corporate liabilities. Journal of Finance 50, 899-917.

Dumas, B., 1991. Super contact and related optimality conditions. Journal of Economic Dynamics and Control 15, 675-685.

Graham, J., 2000. How big are the tax benefits to debt? Journal of Finance 55, 1901-1941.

Harrison, M., Pliska, S., 1981. Martingales and stochastic integrals in the theory of continuous trading. Stochastic Processes and Their Applications 11, 215-260.

He, H., Pindyck, R., 1992. Investment in flexible production capacity. Journal of Economic Dynamics and Control 16, 575-599.

Johnson, H., Stulz, R., 1985. An analysis of secured debt. Journal of Financial Economics 14, 501-521.

Karatzas, I., Shreve, S., 1991. Brownian Motion and Stochastic Calculus, 2nd Edition.. Springer, Berlin.

Kydland, F., Prescott, E., 1982. Time to build and aggregate fluctuations. Econometrica 50, 1345-1370.

Lang, L., Poulsen, A., Stulz, R., 1995. Asset sales, firm performance, and the agency costs of managerial discretion. Journal of Financial Economics 37, 3-37.

Leland, H., 1994. Corporate debt value, bond covenants, and optimal capital structure. Journal of Finance 49, 1213-1252.

Maksimovic, V., Phillips, G., 1998. Efficiency of bankrupt firms and industry conditions: theory and evidence. Journal of Finance 53, 1495-1532.

Mello, A., Parsons, J., 1992. Measuring the agency cost of debt. Journal of Finance 47, 1887-1904.

Myers, S., Rajan, R., 1998. The paradox of liquidity. Quarterly Journal of Economics 113, 733-771.

Pindyck, R., 1988. Irreversible investment, capacity choice, and the value of the firm. American Economic Review 78, 969-985.

Shleifer, A., Vishny, R., 1992. Liquidation values and debt capacity: a market equilibrium approach. Journal of Finance 47, 1343-1366.

Smith, C., Warner, J., 1979a. Bankruptcy, secured debt, and optimal capital structure: a comment. Journal of Finance 34, 247-251. 
Smith, C., Warner, J., 1979b. On financial contracting: an analysis of bond covenants. Journal of Financial Economics 7, 117-161.

Weiss, L., Wruck, K., 1998. Information problems, conflicts of interest, and asset stripping: Chapter 11's failure in the case of Eastern Airlines. Journal of Financial Economics 48, 55-97. 